ARTICLE

\title{
Male sex identified by global COVID-19 meta-analysis as a risk factor for death and ITU admission
}

Hannah Peckham (10) 1,2, Nina M. de Gruijter (10 1,2, Charles Raine (10 2, Anna Radziszewska (1) 1,2, Coziana Ciurtin (1) 1,2, Lucy R. Wedderburn (10) 1,3,4, Elizabeth C. Rosser (1) 1,2,7, Kate Webb (1) ${ }^{5,6,7 凶 \& ~}$ Claire T. Deakin (1) $1,3,4,7 凶$

Anecdotal evidence suggests that Coronavirus disease 2019 (COVID-19), caused by the coronavirus SARS-CoV-2, exhibits differences in morbidity and mortality between sexes. Here, we present a meta-analysis of 3,111,714 reported global cases to demonstrate that, whilst there is no difference in the proportion of males and females with confirmed COVID19, male patients have almost three times the odds of requiring intensive treatment unit (ITU) admission $(\mathrm{OR}=2.84 ; 95 \% \mathrm{Cl}=2.06,3.92)$ and higher odds of death $(\mathrm{OR}=1.39 ; 95 \% \mathrm{Cl}=$ $1.31,1.47)$ compared to females. With few exceptions, the sex bias observed in COVID-19 is a worldwide phenomenon. An appreciation of how sex is influencing COVID-19 outcomes will have important implications for clinical management and mitigation strategies for this disease.

\footnotetext{
${ }^{1}$ Centre for Adolescent Rheumatology Versus Arthritis at UCL, UCLH, GOSH, London, UK. ${ }^{2}$ Centre for Rheumatology Research, Division of Medicine, UCL, London, UK. ${ }^{3}$ Infection, Immunity and Inflammation Research and Teaching Department, UCL Great Ormond Street Institute of Child Health, London, UK. ${ }^{4}$ NIHR Biomedical Research Centre at Great Ormond Street Hospital, London, UK. ${ }^{5}$ Department of Paediatric Rheumatology, School of Child and Adolescent Health, Red Cross War Memorial Children's Hospital, University of Cape Town, Cape Town, South Africa. ${ }^{6}$ The Francis Crick Institute, Crick African Network, London, UK. ${ }^{7}$ These authors contributed equally: Elizabeth C. Rosser, Kate Webb, Claire T. Deakin. ${ }^{凶}$ email: kate.webb@uct.ac.za; c.deakin@ucl.ac.uk
} 
consistent feature of the ongoing coronavirus disease 2019 (COVID-19) pandemic, caused by the novel severe acute respiratory syndrome coronavirus 2 (SARS-CoV-2) $)^{1}$, is the male bias towards severe disease ${ }^{2-6}$. Despite this, there are few analyses addressing whether this is a global rather than regional phenomenon. There are limited data that indicate whether the bias towards increased mortality in males is due to an increased proportion of infections in males, or a true representation of more severe disease. This gap in the literature highlights that sex remains an under-appreciated variable when interrogating outcomes in infectious diseases.

To address whether the reported sex-bias is validated by largescale statistical analysis of global data, we have collected available case data from 90 reports including 46 different countries and 44 US states totalling 3,111,714 infected cases, and present a metaanalysis to investigate sex as a risk factor for SARS-CoV-2 infection, and COVID-19 morbidity and mortality. We demonstrate that while there is no difference in the proportion of males and females infected with SARS-CoV-2, males face higher odds of both intensive therapy unit (ITU) admission and death compared to females. The confirmation of this sex disparity with global data has important implications for the continuing public health response to this pandemic.

\section{Results}

Source selection and inclusion. To interrogate the sex-bias in the global COVID-19 pandemic, 107 reports were gathered from across the world, from 1st January 2020 until the $1^{\text {st }}$ June 2020 (Fig. 1). Reports were included if they contained data on the total number of infections by sex, and the severity of disease as measured by admission to ITU and death $(n=92)$. Most reports $(n=88)$ were government websites, one report was from the British Medical Journal Global Health Blog website, and a minority comprised published research articles $(n=3)$, from which data were captured from full text. Importantly, sex disaggregated data for the United States of America (USA) were only available at individual state levels. Data from individual states were therefore analysed as separate regions to account for differences in how the data may have been collected. Reports were excluded if they did not report the overall number of infections by sex (one ITU case series and three mortality case series), or had small case numbers (less than five). Of the remaining 102 reports, multiple early reports originated from China, which were carefully examined for duplication. Following the exclusion of nine reports due to possible duplication, and one report from Canada with a large percentage of cases with unknown sex, a total of 92 reports from 47 different countries were analysed further (Supplementary Data 1$)^{7-98}$. The 92 reports included three reports from China, the largest of which included data on confirmed cases by sex and mortality by sex, but not ITU admission by sex $^{9}$. For this reason, the other two Chinese reports ${ }^{10,11}$ were included in the analysis of ITU admission by sex, but were excluded from the analyses of confirmed cases and mortality by sex as it was likely these two reports overlapped with the larger report of Chinese cases ${ }^{9}$.

Final reports and cases contributing to analysis: Ninety reports described the sex of $3,111,714$ infected cases in 46 countries and 44 US states. Eight reports, representing 341,571 cases described 12,067 ITU admissions by sex. Seventy-one reports included mortality by sex, and after exclusion of the one possible overlapping report from China, 70 reports describing the sex of 2,751,115 COVID-19 cases and 214,361 related deaths were included in the final analysis. Counts of confirmed male cases and male deaths were calculated for 23 and 13 sources, respectively as these sources reported percentages and not counts. Thirty-four sources included a small proportion of cases of unknown sex and
17 sources included a small proportion of deaths of unknown sex (Supplementary Data 1).

Meta-analyses of infection, ITU and mortality risks: The proportion of male cases with COVID-19 in these reports was exactly half at $0.50(95 \%$ confidence interval $(\mathrm{CI})=0.48,0.51 ; p=$ $0.56 ; n=3,111,714)$, demonstrating that males and females have similar numbers of infections (Fig. 2). Male sex was associated with increased odds of ITU admission (odds ratio $(\mathrm{OR})=2.84$; $95 \% \mathrm{CI}=2.06,3.92 ; p=1.86 \times 10^{-10} ; n=341,571$ ) (Fig. 3), and increased odds of death $(\mathrm{OR}=1.39 ; 95 \% \mathrm{CI}=1.31,1.47 ; p=$ $5.00 \times 10^{-30} ; n=2,751,115$ ) (Fig. 4).

Funnel plots and sensitivity analyses indicated that the results for the estimated proportion of male cases and the estimated OR for ITU admission in men were unlikely to be influenced by reporting bias; however, the estimated OR for mortality in men may be an underestimate (Supplementary Information). Taken together these data highlight that, whilst there is no difference in the proportion of COVID-19 cases between sexes, men have a higher risk of ITU admission (OR 2.84) and death (OR 1.39).

\section{Discussion}

Here we present a large-scale global statistical analysis to show that whilst males and females are at equivalent risk of infection, male sex is associated with the development of severe disease as measured by ITU admission $(\mathrm{OR}=2.84 ; 95 \% \mathrm{CI}=2.06,3.92$; $\left.p=1.86 \times 10^{-10}\right)$ and death $(\mathrm{OR}=1.39 ; 95 \% \mathrm{CI}=1.31,1.47 ; p=$ $\left.5.00 \times 10^{-30}\right)$. Despite this notable feature of the pandemic, sex is still not routinely reported in all available regional data.

Sex differences in the prevalence and outcomes of infectious diseases occur at all ages, with an overall higher burden of bacterial, viral, fungal and parasitic infections in human males ${ }^{99-102}$. Previous coronavirus outbreaks have demonstrated the same sex bias. The Hong Kong SARS-CoV-1 epidemic showed an ageadjusted relative mortality risk ratio of $1.62(95 \% \mathrm{CI}=1.21,2.16)$ for males ${ }^{103}$. During the same outbreak in Singapore, male sex was associated with an odds ratio of $3.10(95 \% \mathrm{CI}=1.64,5.87$; $p \leq 0.001)$ for ITU admission or death ${ }^{104}$. The Saudi Arabian MERS outbreak in 2013 - 2014 exhibited a case fatality rate of $52 \%$ in men and $23 \%$ in women ${ }^{105}$. These data suggest that, whilst socio-economic factors may be influencing some aspects of the pandemic, fundamental differences in the immune response between males and females are likely to be a driving factor behind the significant sex-bias observed in the COVID-19 pandemic.

Sex differences in both the innate and adaptive immune system have been previously reported and may account for the female advantage in COVID-19. Within the adaptive immune system, females have higher numbers of $\mathrm{CD} 4+\mathrm{T}$ cells ${ }^{106-111}$, more robust $\mathrm{CD} 8+\mathrm{T}$ cell cytotoxic activity ${ }^{112}$, and increased $\mathrm{B}$ cell production of immunoglobulin compared to males ${ }^{106,113}$. Women report more severe local and systemic side effects, and produce higher antibody titres in response to the trivalent inactivated seasonal influenza vaccination (TIV) ${ }^{100}$, as well as to most other pathogen vaccines ${ }^{114}$. More specifically, females achieve equivalent protective antibody titres to males at half the dose of TIV $^{115}$, with serum testosterone levels inversely correlating with TIV antibody titres ${ }^{116}$. Female B cells also produce more antigenspecific IgG in response to $\mathrm{TIV}^{117}$. These findings imply that females have an increased capacity to mount humoral immune responses compared to males, and together with the data from this meta-analysis, may have important implications for the development of vaccination strategies for COVID-19.

Females produce more type 1 interferon (IFN), a potent antiviral cytokine, upon toll-like receptor 7 sensing of viral RNA than males ${ }^{18-124}$, which is important for the early response in COVID-19125. Increased IFN production by females is associated 


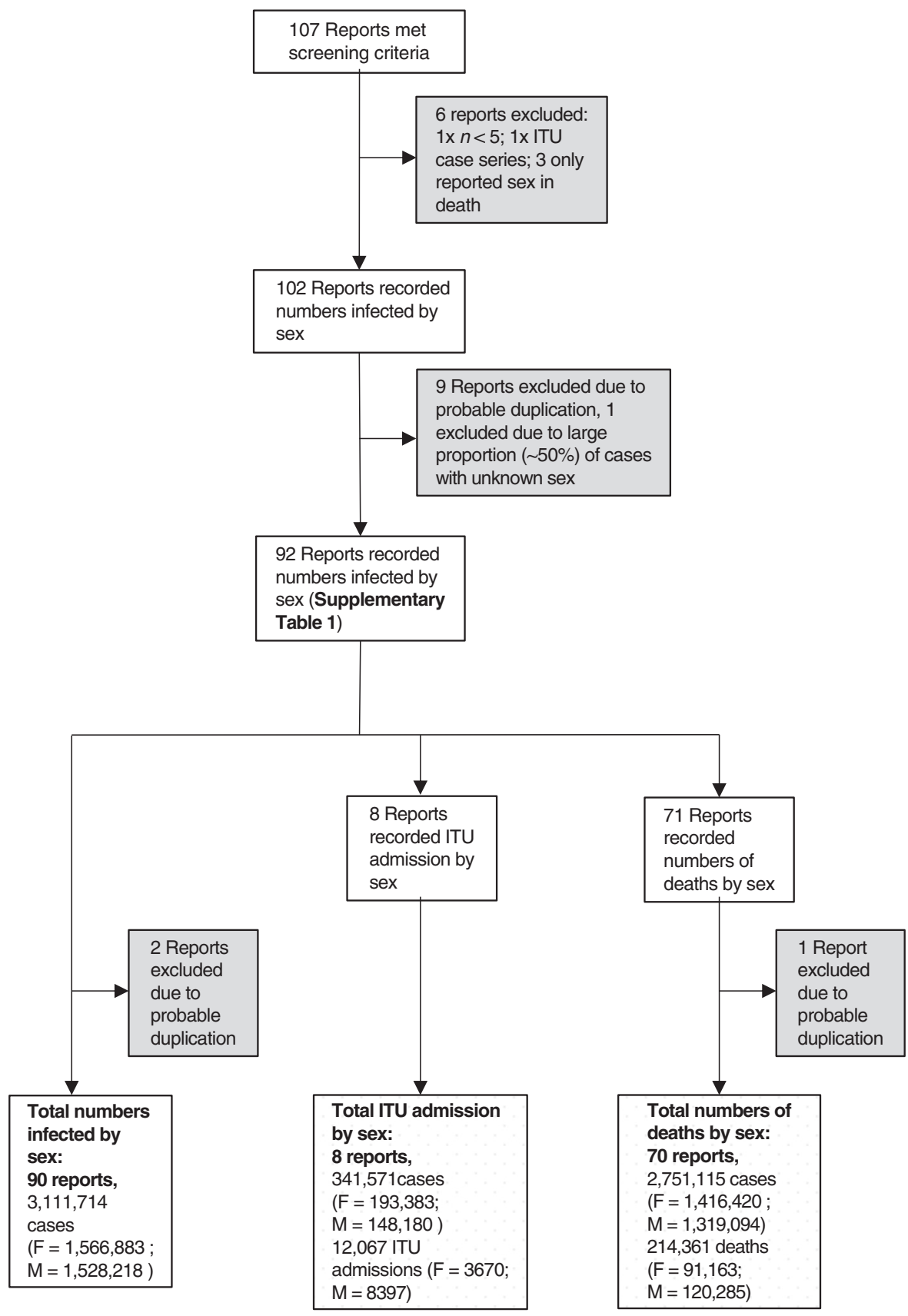

Fig. 1 Study selection. A total of 107 reports were found. Five reports were excluded as they did not report the total number of infections by sex (one intensive therapy unit (ITU) admission only case series and three mortality case series) and one report was excluded as it contained less than five cases. Of the 102 remaining reports, 9 were subsequently excluded due to possible duplication and 1 was excluded due to a large proportion of cases with unknown sex, yielding a total of 92 reports contributing to the analysis. These included three reports from China, which contributed differentially to the analysis. The largest report from China was used for analyses of confirmed cases and mortality by sex with the two other reports from China excluded from those analyses but used for the analysis of ITU admission by sex. This resulted in 90 reports of confirmed cases by sex, eight reports with data on ITU admission by sex and 70 reports with data on mortality by sex. Note that where totals for males and females do not add to the reported totals, this is because sex was unknown for some cases in the original source data.

with both sex hormone concentration and the number of $\mathrm{X}$ chromosomes present ${ }^{119,121}$. The $\mathrm{X}$ chromosome contains many immune-related genes ${ }^{126}$, as evidenced by the existence of many X-linked immunodeficiency disorders ${ }^{127}$. Furthermore Xencoded immune genes may be variably expressed on both alleles in immune cells in females, increasing immune response diversity ${ }^{128,129}$. Oestradiol offers an advantage against infectious disease by augmenting $\mathrm{T}$ cell responses $112,130-132$, increasing antibody production, somatic hyper-mutation and class switching ${ }^{133}$. Oestradiol also increases abundance of neutrophils ${ }^{134}$; and monocyte/macrophage cytokine production ${ }^{135}$.

An early report in pre-print suggested that the declining oestrogen levels in post-menopausal women may be associated with increased inflammatory cytokine production following infection with SARS-CoV-2 ${ }^{136}$. This suggests a potential protective effect of oestradiol against the development of hyperinflammatory immune responses associated with mortality in COVID-19 ${ }^{137}$. In contrast, the male sex hormone testosterone suppresses the 


\begin{tabular}{|c|c|c|c|c|c|}
\hline Source & Infected males & Total infections & Proportion of & of Male ir & nfections \\
\hline Australia, 21/05/2020 (7) & 3598 & 7087 & + & & \\
\hline Belgium, 22/05/2020 (8) & 20,683 & $56,511+$ & & & \\
\hline China, $11 / 02 / 2020(9)$ & 22,981 & 44,672 & + & & \\
\hline Denmark, 19/05/2020 (12) & 4672 & 11,044 & + & & \\
\hline France, $23 / 03 / 2020$ (13) & 2998 & 6378 & $+\vdots$ & & \\
\hline Germany, $21 / 05 / 2020$ (14) & 84,841 & 176,752 & + & & \\
\hline Iran, $15 / 03 / 2020(15)$ & 8545 & 14,991 & & + & \\
\hline Italy, 14/05/2020 (16) & 102,628 & 222,074 & - & & \\
\hline Netherlands, 26/05/2020 (17) & 16,755 & $45,578+$ & & & \\
\hline Norway, 25/05/2020 (18) & 4151 & 8352 & + & & \\
\hline Portugal, 25/05/2020 (19) & 12,975 & 30,788 & + & & \\
\hline South Korea, 26/05/2020 (20) & 4664 & 11,225 & + & & \\
\hline Spain, 22/05/2020 (21) & 106,970 & 248,953 & - & & \\
\hline Switzerland, $26 / 05 / 2020$ (22) & 13,989 & 30,601 & + & & \\
\hline Republic of Ireland, 31/05/2020 (23) & 10,601 & 24,924 & + & & \\
\hline Chile, 07/05/2020 (24) & 13,654 & 25,972 & + & + & \\
\hline Sweden, 26/05/2020 (25) & 14,140 & 34,440 & + & & \\
\hline Finland, $26 / 05 / 2020(26)$ & 3248 & 6628 & - & & \\
\hline Czech Republic, 26/05/2020 (27) & 4336 & 8778 & + & & \\
\hline Romania, 24/05/2020 (28) & 7559 & 18,283 & + & & \\
\hline Austria, 26/05/2020 (29) & 8083 & 16,496 & + & & \\
\hline Saudi Arabia, 25/05/2020 (30) & 54,600 & 74,795 & & & + \\
\hline Greece, 25/05/2020 (31) & 1585 & 2882 & & + & \\
\hline Estonia, 11/05/2020 (32) & 783 & 1741 & + & & \\
\hline Philippines, 26/05/2020 (33) & 7930 & 14,595 & & + & \\
\hline New Zealand, 26/05/2020 (34) & 667 & 1503 & $\rightarrow$ & & \\
\hline Slovenia, 25/03/2020 (35) & 274 & 562 & $\longrightarrow$ & & \\
\hline England, 20/05/2020 (36) & 66,186 & 145,808 & + & & \\
\hline Scotland, 18/05/2020 (37) & 5636 & 14,594 & + & & \\
\hline Pakistan, 23/05/2020 (38) & 44,720 & 57,690 & & & + \\
\hline Colombia, 27/05/2020 (39) & 13,540 & 24,104 & & + & \\
\hline Ecuador, 26/05/2020 (40) & 15,964 & 28,700 & & + & \\
\hline Mexico, 27/05/2020 (41) & 44,473 & 78,023 & & + & \\
\hline Thailand, 24/05/2020 (42) & 1654 & 3040 & & $\leftarrow$ & \\
\hline Luxembourg, $27 / 05 / 2020$ (43) & 2041 & 4001 & 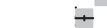 & & \\
\hline Indonesia, 27/05/2020 (44) & 13,496 & 24,538 & & + & \\
\hline Dominican Republic, 26/05/2020 (45) & 8576 & 15,723 & & + & \\
\hline Argentina, 27/05/2020 (46) & 7091 & 13,920 & & & \\
\hline Northern Ireland, 22/05/2020 (47) & 1747 & 4565 & + & & \\
\hline Ghana, 01/06/2020 (48) & 4842 & 8070 & & + & \\
\hline Somalia, 01/06/2020 (49) & 1423 & 1976 & & & + \\
\hline Sierra Leone, 27/05/2020 (50) & 410 & 829 & & & \\
\hline Haiti, 30/05/2020 (51) & 1270 & 2124 & & + & \\
\hline Jamaica, 31/05/2020 (52) & 248 & 586 & $\hookrightarrow$ & & \\
\hline Nigeria, 30/05/2020 (53) & 6631 & 9855 & & & + \\
\hline Bangladesh, 01/06/2020 (54) & 35,169 & 49,534 & & & + \\
\hline New York State, 20/05/2020 (55) & 181,437 & 354,370 & $\therefore$ & & \\
\hline Texas, $21 / 05 / 2020$ (56) & 7583 & 14,456 & + & 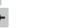 & \\
\hline Illinois, 21/05/2020 (57) & 48,821 & 102,686 & - & & \\
\hline Pennsylvania, 22/05/2020 (58) & 29,153 & 66,258 & + & & \\
\hline Massachusetts, 18/05/2020 (59) & 39,658 & 90,084 & - & & \\
\hline New Jersey, 20/05/2020 (60) & 75,073 & 151,472 & + & & \\
\hline Michigan, $21 / 05 / 2020(61)$ & 25,150 & 53,510 & $+\vdots$ & & \\
\hline California, 20/05/2020 (62) & 43.450 & 86,197 & + & & \\
\hline Washington, 20/05/2020 (63) & 8794 & 19,117 & $+:$ & & \\
\hline Louisiana, 21/05/2020 (64) & 14.602 & 36,504 & + & & \\
\hline Maryland, 22/05/2020 (65) & 21,283 & 44,424 & + & & \\
\hline Virginia, 22/05/2020 (66) & 17,285 & 34,950 & + & & \\
\hline North Carolina, 22/05/2020 (67) & 10,418 & 21,262 & + & & \\
\hline South Carolina, 22/05/2020 (68) & 4067 & 9638 & + & & \\
\hline Alabama, 29/05/2020 (69) & 6800 & 16,530 & + & & \\
\hline Mississippi, 27/05/2020 (70) & 4915 & 12,147 & + & & \\
\hline $\begin{array}{l}\text { Ohio, } 29 / 05 / 2020(71) \\
\text { (7) }\end{array}$ & 16,445 & 31,625 & + & - & \\
\hline Arkansas, 29/05/2020 (72) & 3906 & 6538 & & + & \\
\hline Indiana, 29/05/2020 (73) & 15,230 & 33,068 & + & & \\
\hline Wisconsin, 29/05/2020 (74) & 8657 & 16,974 & + & & \\
\hline Minnesota, 28/05/2020 (75) & 11,051 & 22,947 & + & & \\
\hline Florida, 28/05/2020 (76) & 25,611 & 51,918 & + & & \\
\hline Kentucky. 29/05/2020 (77) & 4328 & 9185 & $+:$ & & \\
\hline lowa, 29/05/2020 (78) & 9583 & 18,791 & + & & \\
\hline Missouri, 29/05/2020 (79) & 6826 & 12,673 & & + & \\
\hline Connecticut, 28/05/2020 (80) & 18,662 & 41,559 & + & & \\
\hline Rhode Island, 29/05/2020 (81) & 6439 & 14,635 & + & & \\
\hline New Hampshire, 18/05/2020 (82) & 2006 & 3652 & & $\rightarrow$ & \\
\hline Vermont, 29/05/2020 (83) & 458 & 975 & $\rightarrow$ & & \\
\hline Maine, 29/05/2020 (84) & 1072 & 2226 & + & & \\
\hline Oklahoma, 29/05/2020 (85) & 2986 & 6338 & -: & & \\
\hline Alaska, 29/05/2020 (86) & 220 & 430 & $\div$ & — & \\
\hline Arizona, 29/05/2020 (87) & 8679 & 18,465 & $+:$ & & \\
\hline Colorado, 29/05/2020 (88) & 12,088 & 25,121 & + & & \\
\hline Delaware, 29/05/2020 (89) & 4117 & 9236 & $+\vdots$ & & \\
\hline West Virginia, 29/05/2020 (90) & 911 & 1951 & - & & \\
\hline Oregon, $19 / 05 / 2020(91)$ & 1727 & 3660 & $\mp:$ & & \\
\hline North Dakota, 29/05/2020 (92) & 1188 & 2520 & + & & \\
\hline New Mexico, 29/05/2020 (93) & 3462 & 7364 & + : & & \\
\hline Nevada, 29/05/2020 (94) & 3887 & 8350 & + & & \\
\hline Montana, 15/05/2020 (95) & 225 & 468 & & & \\
\hline Kansas, 29/05/2020 (96) & 5358 & 9719 & & + & \\
\hline Idaho, 29/05/2020 (97) & 1249 & 2769 & $+\vdots$ & & \\
\hline Wyoming, 29/05/2020 (98) & 331 & 667 & & & \\
\hline Random effects model & & $3,111,714$ & $\therefore$ & & \\
\hline & & & & 0.6 & 0.7 \\
\hline
\end{tabular}

Fig. 2 There is no observed sex difference in the proportion of people with COVID-19. The table summarises the number of confirmed male COVID-19 cases and the total number of COVID-19 cases in 90 reports. The forest plot illustrates the estimated proportion of male cases for each report (grey boxes), with $95 \%$ confidence intervals ( $\mathrm{Cl}$; horizontal black lines). The estimated pooled proportion of male cases (dark grey diamond) was 0.5 ( $95 \% \mathrm{Cl}=$ $0.48,0.51)$. A two-sided test confirmed the estimated pooled proportion was not significantly different from $0.5(p=0.56)$, indicating no difference between the proportions of male and female infections. Meta-analysis used a random effects model, which accounted for variance across reports and used the indicated weights for each report. 


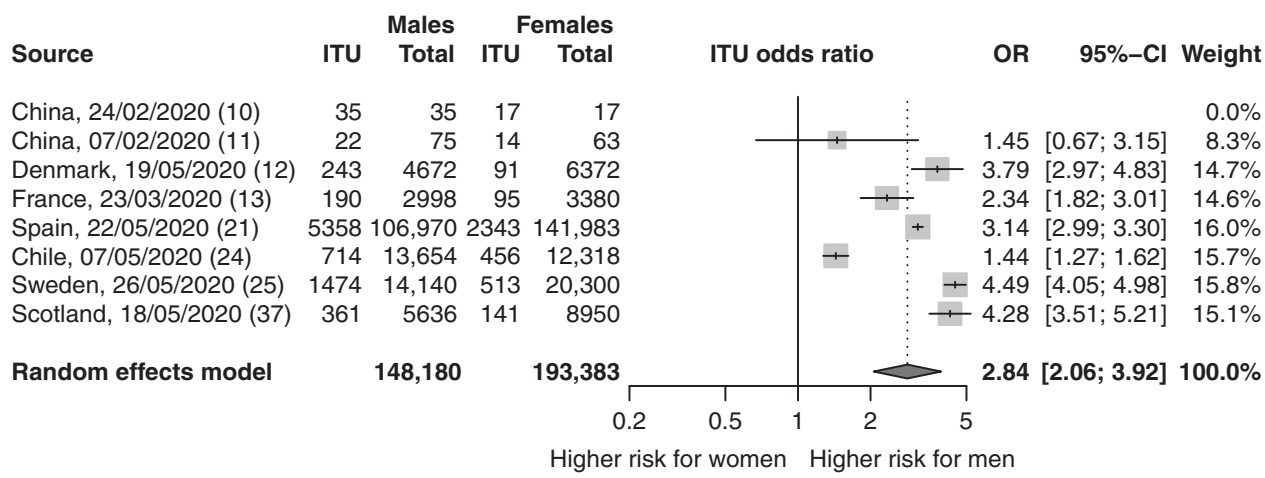

Fig. 3 Male sex is associated with a significantly increased risk of ITU admission within COVID-19 patients. The table summarises the number of ITU admissions and total number of confirmed COVID-19 cases for each sex for $n=8$ reports with complete data on SARS-CoV-2 infections and ITU admissions in males and females. The forest plot represents the estimated odds ratio (OR) for the association of ITU admission with male sex for each report (grey boxes), with 95\% confidence intervals ( $\mathrm{Cl}$; horizontal black lines). The estimated pooled OR (dark grey diamond) was $2.84(95 \% \mathrm{Cl}=2.06$, 3.92). A two-sided test confirmed the estimated pooled OR was significantly different from $1\left(p=1.86 \mathrm{e}^{10}\right)$. Meta-analysis used a random effects model with individual reports weighted using the indicated weights.

immune system: hypo-androgenism is associated with increased inflammatory cytokines, antibody titres, CD4/CD8 ratios, and natural killer cells, and a decrease in regulatory $\mathrm{T}$ cells ${ }^{101,138}$. Interestingly, testosterone-deprivation therapy for prostate cancer has been associated with improved outcomes for COVID-19, suggesting that suppression of the immune response by testosterone, as well as the protective effect of oestrogen, may underlie the observed sex-bias ${ }^{139}$.

Age-related changes in the immune system are also different between sexes ${ }^{140}$ and there is a marked association between morbidity/mortality and advanced age in COVID-19. For example, males show an age-related decline in B cells and a trend towards accelerated immune ageing ${ }^{141,142}$. This may further contribute to the sex bias seen in COVID-19.

Other biological factors may influence the sex-bias observed in this study. Expression of angiotensin converting enzyme 2 (ACE2) receptors - which facilitate SARS-CoV-2 viral entry and human to human transmission ${ }^{143}$ - is different between the sexes $^{144,145}$. Oestradiol may influence ACE2 expression ${ }^{146}$, and the gene for ACE2 is located in the $\mathrm{X}$ chromosome ${ }^{147}$, which may render it susceptible to escaping X-inactivation in women.

Sex-based differences in co-morbidities that are associated with severe COVID-19 may also drive some of the differences observed in this study. However, due to the nature of these high level, publicly available summary data, metadata including age, ethnicity and comorbidities for individual cases are not available. The lack of adjustment for these factors limits our ability to accurately predict the role of sex in disease severity. Notably, there are no marked sex differences in the proportions of adults globally with hypertension (33\% of women vs $36 \%$ of men $)^{148}$ or diabetes ( $9 \%$ of women vs $9.6 \%$ of men) ${ }^{149}$, the most common reported comorbidities in hospitalised COVID-19 patients ${ }^{150}$. Once more data become available, future studies can adjust for additional factors using techniques such as mediation analysis.

Gender-based socio-cultural and behavioural differences could contribute to the sex difference seen in COVID-19 disease severity. Men are more likely to smoke ${ }^{151}$, although smoking has not emerged as a clear risk factor for severe disease ${ }^{144}$. Men are less likely to wash their hands with soap after entering a restroom $^{152}$, and in many cultures, men may be more likely to leave the house and enter crowded areas. Unequal access to healthcare and testing between sexes may skew towards a male bias in infection rates. The data, however, show no difference in the numbers of infected cases between sexes overall, so gender differences in hygiene behaviours and testing are unlikely to explain the sex disparity in disease severity. Regional gender differences in health-seeking behaviours and access to care may predispose men towards access to hospital and ITU admis$\operatorname{sion}^{153-156}$. However, the ubiquitous nature of the sex-bias in these data argues for a true biological difference in the response to SARS-CoV-2 between sexes.

These large-scale data demonstrate that although there is no sex difference in the proportion of people infected with SARSCoV-2, males are at a significantly higher risk of severe disease and death than females. Previous reports describe fundamental differences between sexes in the immune response to infection, which include a more robust antiviral innate interferon response and increased adaptive immunity towards viral antigens in females. In people infected with SARS-CoV-2 these differences are likely to lead to more effective viral control in females, which may contribute to the relatively lower risk of developing severe disease. Although further studies are needed, these data have implications for the clinical management of COVID-19 and highlight the importance of considering sex as a variable in fundamental and clinical research.

\section{Methods}

Search strategy. An online search of government websites and published literature was performed by multiple researchers working remotely for regional data reports on COVID-19 cases that included sex as a variable from 01 January 2020 up until 01 June 2020 (Search terms: SARS-CoV-2/COVID-19/case/sex/country/ data/death/ICU/ITU). In order to ensure unbiased representation from as many regions as possible, a cross check was done using the list of countries reporting data on 'Worldometer' 157 , and an attempt was made to include as many regions reporting sex data as possible. Reports were translated using Google translate if they were not in English.

Data selection, extraction and synthesis. Reports were included if they contained sex as a variable in data describing case number, ITU admission, or mortality. Data were entered directly by individual researchers into an online structured data extraction table. For some sources, counts of male confirmed cases or male deaths were not provided, but percentages of male cases or male deaths were provided instead. To include these sources and avoid biases that might be introduced by their exclusion, we calculated counts of male confirmed cases and male deaths from the reported percentages with rounding to the nearest integer. We acknowledge that this approach assumes that the reported percentages are reflective of the true percentages. For some sources, data included confirmed cases and deaths of unknown sex. For these sources, the reported totals were used where the proportion of unknown sex was small (see Supplementary Data 1). This approach was preferred to excluding cases of unknown sex in order to avoid bias. The estimates represent the proportion of known male infections and ORs for mortality associated with known male sex, and will differ slightly from what the true values would be if the sex had been reported for all cases. Data were available at the level of country or regional summary data representing distinct individuals 


\section{Source}

Australia, 21/05/2020 (7)

Belgium, 22/05/2020 (8)

China, 11/02/2020 (9)

Denmark, 19/05/2020 (12)

France, 23/03/2020 (13)

Germany, 21/05/2020 (14)

Iran, 15/03/2020 (15)

Italy, 14/05/2020 (16)

Netherlands, 26/05/2020 (17)

Norway, 25/05/2020 (18)

Portugal, 25/05/2020 (19)

South Korea, 26/05/2020 (20)

Spain, 22/05/2020 (21)

Switzerland, 26/05/2020 (22)

Chile, 07/05/2020 (24)

Sweden, 26/05/2020 (25)

Finland, 26/05/2020 (26)

Czech Republic, 26/05/2020 (27)

Romania, 24/05/2020 (28)

Austria, 26/05/2020 (29)

Greece, 25/05/2020 (31)

Estonia, 11/05/2020 (32)

Philippines, 26/05/2020 (33)

England, 20/05/2020 (36)

Scotland, 18/05/2020 (37)

Pakistan, 23/05/2020 (38)

Colombia, 27/05/2020 (39)

Ecuador, 26/05/2020 (40)

Mexico, 27/05/2020 (41)

Thailand, 24/05/2020 (42)

Luxembourg, 27/05/2020 (43)

Indonesia, 27/05/2020 (44)

Dominican Republic, 26/05/2020 (45)

Argentina, 27/05/2020 (46)

Northern Ireland, 22/05/2020 (47)

New York State, 20/05/2020 (55)

Texas, 21/05/2020 (56)

Illinois, 21/05/2020 (57)

Pennsylvania, 22/05/2020 (58)

Massachusetts, 18/05/2020 (59)

Michigan, 21/05/2020 (61)

California, 20/05/2020 (62)

Washington, 20/05/2020 (63)

Louisiana, 21/05/2020 (64)

Maryland, 22/05/2020 (65)

Virginia, 22/05/2020 (66)

North Carolina, 22/05/2020 (67)

South Carolina, 22/05/2020 (68)

Alabama, 29/05/2020 (69)

Mississippi, 27/05/2020 (70)

Ohio, 29/05/2020 (71)

Indiana, 29/05/2020 (73)

Wisconsin, 29/05/2020 (74)

Minnesota, 28/05/2020 (75)

Florida, 28/05/2020 (76)

Kentucky, 29/05/2020 (77)

lowa, 29/05/2020 (78)

Connecticut, 28/05/2020 (80)

Rhode Island, 29/05/2020 (81)

New Hampshire, 18/05/2020 (82)

Vermont, 29/05/2020 (83)

Oklahoma, 29/05/2020 (85)

Arizona, 29/05/2020 (87)

Colorado, 29/05/2020 (88)

Delaware, 29/05/2020 (89)

Oregon, 19/05/2020 (91)

Nevada, 29/05/2020 (94)

Montana, 15/05/2020 (95)

Kansas, 29/05/2020 (96)

Idaho, 29/05/2020 (97)

Random effects model

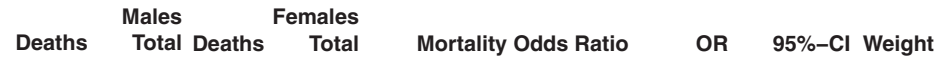

$\begin{array}{lllll}56 & 3598 & 44 & 3489\end{array}$

$\begin{array}{llll}3318 & 20,683 & 3234 & 35,598\end{array}$

$\begin{array}{llrr}653 & 22,981 & 370 & 21,691\end{array}$

$\begin{array}{llll}314 & 4672 & 237 & 6372\end{array}$

$\begin{array}{llll}94 & 2998 & 67 & 3380\end{array}$

$\begin{array}{rrrr}4515 & 84,841 & 3627 & 91,911 \\ 503 & 8545 & 350 & 6446\end{array}$

$\begin{array}{llll}17,877 & 102,628 & 11,815 & 119,267\end{array}$

$\begin{array}{llll}3240 & 16,755 & 2616 & 28,733\end{array}$

$\begin{array}{llll}128 & 4151 & 107 & 4201\end{array}$

$\begin{array}{llll}649 & 12,975 & 681 & 17,813\end{array}$

$\begin{array}{llll}142 & 4664 & 127 & 6561\end{array}$

$\begin{array}{llll}11,608 & 10,6970 & 8928 & 141,983\end{array}$

$\begin{array}{lllll}948 & 13,989 & 697 & 16,612\end{array}$

$\begin{array}{llll}175 & 13,654 & 119 & 12,318\end{array}$

$\begin{array}{llll}2274 & 14,140 & 1851 & 20,300\end{array}$

$\begin{array}{llll}134 & 3248 & 151 & 3380\end{array}$

$\begin{array}{llll}185 & 4336 & 132 & 4442\end{array}$

$\begin{array}{llll}699 & 7559 & 487 & 10,724\end{array}$

$\begin{array}{rrrr}367 & 8083 & 276 & 8413 \\ 121 & 1585 & 51 & 1297\end{array}$

$\begin{array}{ll}51 & 1297 \\ 31 & 958\end{array}$

$\begin{array}{rrrr}30 & 783 & 31 & 958 \\ 571 & 7930 & 315 & 6665 \\ 8,684 & 66,186 & 13,134 & 77,540\end{array}$

$\begin{array}{rrrr}1791 & 5636 & 1755 & 8950\end{array}$

$\begin{array}{rrrr}811 & 44,720 & 256 & 12,970\end{array}$

$\begin{array}{llll}495 & 13,540 & 308 & 10,564\end{array}$

$\begin{array}{llll}2139 & 15,964 & 1082 & 12,736\end{array}$

$\begin{array}{llll}5760 & 44,473 & 2837 & 33,550\end{array}$

$\begin{array}{llll}43 & 1654 & 13 & 1386\end{array}$

$\begin{array}{llll}62 & 2041 & 48 & 1960\end{array}$

$\begin{array}{llll}942 & 13,496 & 554 & 11,042\end{array}$

$\begin{array}{llll}332 & 8576 & 142 & 7147\end{array}$

$\begin{array}{llll}294 & 7091 & 202 & 6784\end{array}$

$\begin{array}{llll}260 & 1747 & 243 & 2750\end{array}$

$\begin{array}{llll}13,352 & 181,437 & 9615 & 171,161\end{array}$

$\begin{array}{llll}268 & 7583 & 190 & 6593\end{array}$

$\begin{array}{llll}2560 & 48,821 & 2042 & 51,690\end{array}$

$\begin{array}{llll}2406 & 29,153 & 2578 & 36,420\end{array}$

$\begin{array}{llll}2954 & 39,658 & 3189 & 49,077\end{array}$

$\begin{array}{llll}2718 & 25150 & 2411 & 28360\end{array}$

$\begin{array}{llll}1926 & 43,450 & 1521 & 42,252\end{array}$

$\begin{array}{lrrr}574 & 8794 & 470 & 9941\end{array}$

$\begin{array}{llll}1363 & 14,602 & 1143 & 20,077\end{array}$

$\begin{array}{llll}1054 & 21,283 & 1038 & 23,141\end{array}$

$\begin{array}{llll}573 & 17,285 & 560 & 17,425\end{array}$

$\begin{array}{llll}378 & 10,418 & 349 & 10,844\end{array}$

$\begin{array}{llll}218 & 4067 & 201 & 5339\end{array}$

$\begin{array}{llll}319 & 6800 & 270 & 9600\end{array}$

$\begin{array}{llll}341 & 4915 & 352 & 7232\end{array}$

$\begin{array}{rrrr}1092 & 16,445 & 1004 & 14,864\end{array}$

$\begin{array}{llll}954 & 15,230 & 904 & 17,040\end{array}$

$\begin{array}{llll}312 & 8657 & 238 & 8317\end{array}$

$\begin{array}{llll}492 & 11,051 & 465 & 11,433\end{array}$

$\begin{array}{llll}1372 & 25,611 & 1074 & 26,262\end{array}$

$\begin{array}{llll}181 & 4328 & 228 & 4608\end{array}$

$\begin{array}{llll}270 & 9583 & 250 & 8832\end{array}$

$\begin{array}{llll}1858 & 18,662 & 1962 & 22,702\end{array}$

$\begin{array}{lrrr}326 & 6439 & 367 & 8196\end{array}$

$\begin{array}{rrrr}92 & 2006 & 80 & 1617 \\ 31 & 458 & 24 & 513\end{array}$

$\begin{array}{rrrr}31 & 458 & 24 & 513 \\ 171 & 2986 & 158 & 3338\end{array}$

$\begin{array}{llll}171 & 2986 & 158 & 3338 \\ 486 & 8679 & 398 & 9756\end{array}$

$\begin{array}{lllr}789 & 12,088 & 628 & 12,759\end{array}$

$\begin{array}{llll}169 & 4117 & 187 & 5091\end{array}$

$\begin{array}{llll}80 & 1727 & 58 & 1929\end{array}$

$\begin{array}{rrrr}237 & 3887 & 171 & 4142\end{array}$

$\begin{array}{rrrr}9 & 225 & 7 & 243 \\ 107 & 5358 & 101 & 4180 \\ 39 & 1249 & 43 & 1513\end{array}$

$39 \quad 1249$

$1,319,094$
Mortality Odds Ratio

$1.24[0.83 ; 1.84] \quad 0.9 \%$

$1.91[1.82 ; 2.01] \quad 1.7 \%$

$1.69[1.48 ; 1.92] \quad 1.6 \%$

$1.87[1.57 ; 2.22] \quad 1.5 \%$

$1.60[1.17 ; 2.20] \quad 1.1 \%$

$1.09[0.95 ; 1.25] \quad 1.5 \%$

$1.92[1.87 ; 1.97] \quad 1.7 \%$

$2.39[2.26 ; 2.53] \quad 1.7 \%$

$1.22[0.94 ; 1.58] \quad 1.2 \%$

$1.32[1.19 ; 1.48] \quad 1.6 \%$

$1.59[1.25 ; 2.03] \quad 1.3 \%$

$1.81[1.76 ; 1.87] \quad 1.7 \%$

$1.66[1.50 ; 1.84] \quad 1.6 \%$

$1.33[1.05 ; 1.68] \quad 1.3 \%$

$1.91[1.79 ; 2.04] \quad 1.7 \%$

$0.92[0.73 ; 1.17] \quad 1.3 \%$

$1.46[1.16 ; 1.83] \quad 1.3 \%$

$2.14[1.90 ; 2.41] \quad 1.6 \%$

$1.40[1.20 ; 1.64] \quad 1.5 \%$

$2.02[1.44 ; 2.83] \quad 1.1 \%$

$1.19[0.71 ; 1.99] \quad 0.7 \%$

$1.56[1.36 ; 1.80] \quad 1.5 \%$

$1.93[1.88 ; 1.98] \quad 1.7 \%$

$1.91[1.77 ; 2.06] \quad 1.6 \%$

$0.92[0.80 ; 1.06] \quad 1.5 \%$

$1.26[1.09 ; 1.46] \quad 1.5 \%$

$1.67[1.54 ; 1.80] \quad 1.6 \%$

$1.61[1.54 ; 1.69] \quad 1.7 \%$

$2.82[1.51 ; 5.26] \quad 0.6 \%$

$1.25[0.85 ; 1.83] \quad 1.0 \%$

$1.42[1.27 ; 1.58] \quad 1.6 \%$

$1.99[1.63 ; 2.42] \quad 1.4 \%$

$1.41[1.17 ; 1.69] \quad 1.4 \%$

$1.80[1.50 ; 2.17] \quad 1.4 \%$

$1.33[1.30 ; 1.37] \quad 1.7 \%$

$1.23[1.02 ; 1.49] \quad 1.4 \%$

$1.35[1.27 ; 1.43] \quad 1.7 \%$

$1.18[1.11 ; 1.25] \quad 1.7 \%$

$1.16[1.10 ; 1.22] \quad 1.7 \%$

$1.30[1.23 ; 1.38] \quad 1.7 \%$

$1.24[1.16 ; 1.33] \quad 1.7 \%$

$1.41[1.24 ; 1.60] \quad 1.6 \%$

$1.71[1.57 ; 1.85] \quad 1.6 \%$

$1.11[1.02 ; 1.21] \quad 1.6 \%$

$1.03[0.92 ; 1.16] \quad 1.6 \%$

$1.13[0.98 ; 1.31] \quad 1.5 \%$

$1.45[1.19 ; 1.76] \quad 1.4 \%$

$1.70[1.44 ; 2.01] \quad 1.5 \%$

$1.46[1.25 ; 1.70] \quad 1.5 \%$

$0.98[0.90 ; 1.07] \quad 1.6 \%$

$1.19[1.09 ; 1.31] \quad 1.6 \%$

$1.27[1.07 ; 1.51] \quad 1.5 \%$

$1.10[0.97 ; 1.25] \quad 1.6 \%$

$1.33[1.22 ; 1.44] \quad 1.6 \%$

$0.84[0.69 ; 1.02] \quad 1.4 \%$

$1.00[0.84 ; 1.18] \quad 1.5 \%$

$1.17[1.09 ; 1.25] \quad 1.7 \%$

$1.14[0.98 ; 1.33] \quad 1.5 \%$

$0.92[0.68 ; 1.26] \quad 1.1 \%$

$1.48[0.85 ; 2.56] \quad 0.7 \%$

$1.22[0.98 ; 1.53] \quad 1.3 \%$

$1.39[1.22 ; 1.60] \quad 1.5 \%$

$1.35[1.21 ; 1.50] \quad 1.6 \%$

$1.12[0.91 ; 1.39] \quad 1.4 \%$

$1.57[1.11 ; 2.21] \quad 1.0 \%$

$1.51[1.23 ; 1.84] \quad 1.4 \%$

$1.40[0.51 ; 3.84] \quad 0.3 \%$

$0.82[0.63 ; 1.08] \quad 1.2 \%$

$1.39[1.31 ; 1.47] 100.0 \%$
$1.37[1.31 ; 1.43] \quad 1.7 \%$

$1.10[0.71 ; 1.71]-0.8 \%$

Higher risk for women

Fig. 4 Male sex is associated with a significantly increased risk of mortality within COVID-19 patients. The table summarises the number of deaths and total number of confirmed COVID-19 cases for each sex for $n=70$ reports with complete data on infection and mortality in males and females. The forest plot illustrates the estimated odds ratio (OR) for the association of death with male sex for each report (grey boxes) with $95 \%$ confidence intervals (Cl; horizontal black lines). The estimated pooled OR (dark grey diamond) was 1.39 ( $95 \% \mathrm{Cl}=1.31,1.47)$. A two-sided test confirmed the estimated pooled OR was significantly different from $1\left(p=5.00 \mathrm{e}^{-30}\right)$. Meta-analysis used a random effects model with individual reports weighted using the indicated weights. 
for each report, but not at the level of covariates for all individuals within a study. Consequently, covariates such as lifestyle, comorbidities, testing method and case type (hospital vs. community) could not be controlled for. Data represent unique individuals at a single time snapshot. All data are provided in Supplementary Data $1^{7-98}$ and https://doi.org/10.25375/uct.12952151.

Data analysis. Meta-analysis was performed to estimate an overall proportion of male infected cases with 95\% CI. This meta-analysis was two-sided and tested the null hypothesis that the proportion of male infected cases was 0.5 . For this analysis, the classic inverse variance method for estimation of single proportions and standard errors was used, which uses logit-transformed proportions. The inverse variance method accounts for differing sample sizes of individual studies by weighting studies by the variance of their estimates, such that small studies with large variance have less weighting, and large studies with small variance have more weighting. A sensitivity analysis was also performed, in which the generalised linear mixed model (GLMM) method was used to estimate an overall proportion. This yielded identical results, indicating the differing assumptions of these different methods were inconsequential for these data.

Meta-analyses were also performed to estimate ORs with 95\% CI associated with male sex for ITU admission and death, based on pooled average effect measures that were weighted according to the size and precision of each report. Random effects models were estimated and are reported rather than fixed effects models, since these do not assume uniformity across reports and account for variance between reports. The Mantel-Haenszel and DerSimonian-Laird methods were used to calculate the fixed effects and random effects estimates, respectively. Similar to the inverse variance weighting method, individual studies are weighted according to size and variance, and estimates were almost identical when the inverse variance weighting method was used. Both of these meta-analyses for the ITU admission and death outcomes were two-sided and tested the null hypothesis that the estimated OR was 1 . Reports that did not contain the data required to calculate ORs were automatically excluded from meta-analyses.

Meta-analyses were performed using $\mathrm{R}$ version 3.6.1 and the "meta" package version 4.11-0158. All $\mathrm{R}$ code and input data are available at https://github.com/ claire-deakin/covid19-sex-bias and at https://doi.org/10.25375/uct.12952151.

Reporting Summary. Further information on research design is available in the Nature Research Reporting Summary linked to this article.

\section{Data availability}

All data contributing to this analysis are provided in Supplementary Data 1 and published at figshare (https://doi.org/10.25375/uct.12952151). Screenshots of all sources from date of access are archived and may be available on request.

\section{Code availability.}

The $\mathrm{R}$ code and input data used for all analyses are available at https://github.com/clairedeakin/covid19-sex-bias and at https://doi.org/10.25375/uct.12952151.

Received: 16 April 2020; Accepted: 23 October 2020;

Published online: 09 December 2020

\section{References}

1. Gorbalenya, A. E. et al. The species Severe acute respiratory syndrome-related coronavirus: classifying $2019-\mathrm{nCoV}$ and naming it SARS-CoV-2. Nat. Microbiol. 5, 536-544 (2020).

2. Scully, E. P., Haverfield, J., Ursin, R. L., Tannenbaum, C. \& Klein, S. L. Considering how biological sex impacts immune responses and COVID-19 outcomes. Nat. Rev. Immunol. 20, 442-447 (2020).

3. Richardson, S. et al. Presenting Characteristics, Comorbidities, and Outcomes Among 5700 Patients Hospitalized With COVID-19 in the New York City Area. JAMA 323, 2052 (2020).

4. Singh, S., Chowdhry, M., Chatterjee, A. \& Khan, A. Gender-Based Disparities in COVID-19: Clinical Characteristics and Propensity-matched Analysis of Outcomes. medRxiv https://doi.org/10.1101/2020.04.24.20079046 (2020).

5. Kragholm, K. et al. Association between male sex and outcomes of Coronavirus Disease 2019 (Covid-19) - a Danish nationwide, register-based study. Clin. Infect. Dis. https://doi.org/10.1093/cid/ciaa924 (2020).

6. Jin, J.-M. et al. Gender Differences in Patients With COVID-19: Focus on Severity and Mortality. Front. Public Heal. 8, 152 (2020).

7. Australian Government Department of Health. Coronavirus (COVID-19) current situation and case numbers|Australian Government Department of Health. https://www.health.gov.au/news/health-alerts/novel-coronavirus2019-ncov-health-alert/coronavirus-covid-19-current-situation-and-casenumbers\#total-cases-recoveries-and-deaths (2020).
8. L'institut de Santé Sciensano. Epistat - Covid-19 Belgium Epidemiological Situation https://epistat.wiv-isp.be/Covid/covid-19.html (2020).

9. Yang, X. et al. Clinical course and outcomes of critically ill patients with SARS-CoV-2 pneumonia in Wuhan, China: a single-centered, retrospective, observational study. Lancet Respir. Med. https://doi.org/10.1016/S2213-2600 (20)30079-5 (2020).

10. The Novel Coronavirus Pneumonia Emergency Response Epidemiology Team. The Epidemiological Characteristics of an Outbreak of 2019 Novel Coronavirus Diseases (COVID-19) - China, 2020. China CDC Wkly. 2, 113-122 (2020)

11. Wang, D. et al. Clinical Characteristics of 138 Hospitalized Patients With 2019 Novel Coronavirus-Infected Pneumonia in Wuhan, China. JAMA 323, 1061-1069 (2020).

12. Statens Serum Institut. COVID-19 i Danmark - Epidemiologisk overvågningsrapport - 19-05-2020 - data opdateret kl. 08:00. https://files.ssi.dk/ COVID19-overvaagningsrapport-19052020-d218 (2020).

13. Sante Publique France. COVID-19: point épidémiologique du 15 mars 2020. https://www.santepubliquefrance.fr/maladies-et-traumatismes/maladies-etinfections-respiratoires/infection-a-coronavirus/documents/bulletin-national/ covid-19-point-epidemiologique-du-15-mars-2020 (2020).

14. Robert Koch Institute. Coronavirus Disease 2019 (COVID-19) Daily Situation Report of the Robert Koch Institute. https://www.rki.de/DE/ Content/InfAZ/N/Neuartiges_Coronavirus/Situationsberichte/2020-05-21en.pdf?__blob=publicationFile (2020).

15. Purdie, A. et al. Sex, Gender and COVID-19: Disaggregated Data and Health Disparities https://blogs.bmj.com/bmjgh/2020/03/24/sex-gender-and-covid19-disaggregated-data-and-health-disparities/ (2020).

16. Riccardo, F. et al. Epidemia COVID-19 - Aggiornamento nazionale 14 maggio 2020 - ore 16:00 - Prodotto dall'Istituto Superiore di Sanità (ISS). https://www. epicentro.iss.it/coronavirus/bollettino/Bollettino-sorveglianza-integrataCOVID-19_14-maggio-2020.pdf (2020).

17. RIVM Nederlands. Epidemiologische situatie COVID-19 in Nederland Rijksinstituut voor Volksgezondheid en Milieu - RIVM 26 mei 2020, 10:00. https://www.rivm.nl/coronavirus-covid-19/grafieken (2020).

18. Folkehelseinstituttet. COVID-19 Dagsrapport mandag 25. mai 2020. https:// www.fhi.no/contentassets/e110607a67df46cbba8e30a443264a73/vedlegg/ 2020.05.25-dagsrapport-norge-covid-19.pdf (2020).

19. Ministry of Health Portugal. COVID-19 RELATÓRIO DE SITUAÇÃO 24 MAIO. https://www.dgs.pt/em-destaque/relatorio-de-situacao-n-08324052020.aspx (2020).

20. KCDC. Updates on COVID-19 in Republic of Korea https://www.cdc.go.kr/ board/board.es? $\mathrm{mid}=$ a30402000000\&bid $=0030(2020)$.

21. Gobierno de Espana Ministerio De Sanidad. Actualización $n^{0} 113$. Enfermedad por el coronavirus (COVID-19). 22.05.2020 (datos consolidados a las 00:00 horas del 22.05.2020) SITUACIÓN EN ESPAÑA. https://www.mscbs.gob.es/ profesionales/saludPublica/ccayes/alertasActual/nCov-China/documentos/ Actualizacion_113_COVID-19.pdf (2020).

22. L'Office fédéral de la santé publique. COVID-19 - Situation Suisse: Répartition par canton, âge et sexe 26-5-20 https://covid-19-schweiz.bagapps.ch/fr-1.html (2020).

23. Republic of Ireland Department of Health. Statement from the National Public Health Emergency Team - Sunday 31 May https://www.gov.ie/en/pressrelease/be38b-statement-from-the-national-public-health-emergency-teamsunday-31-may/ (2020)

24. Gobierno de Chile, M. de S. Informe Ejecutivo Sobre La Situación Epidemiológica https://epivigila.minsal.cl/ (2020).

25. Folkhälsomyndigheten Sweden. FOHM Covid-19 https://experience.arcgis. com/experience/09f821667ce64bf7be6f9f87457ed9aa (2020).

26. Finnish Institute for Health and Welfare. Situation Update On Coronavirus 26 May 17.05 https://thl.fi/en/web/infectious-diseases/what-s-new/coronaviruscovid-19-latest-updates/situation-update-on-coronavirus\#Coronavirusrelated_deaths (2020).

27. Ministerstvo zdravotnictví České republiky. COVID-19: Přehled Aktuálni Situace $v$ ČR 26-5-2020 https://onemocneni-aktualne.mzcr.cz/covid-19 (2020).

28. INSP Romania. Covid 19 Raport saptamanal de supraveghere Date raportate pana la data de 24 mai. https://www.cnscbt.ro/index.php/analiza-cazuriconfirmate-covid19/1789-raport-saptamanal-episaptamana22/file (2020).

29. Bundesministerium für Soziales Gesundheit Pflege und Konsumentenschutz. Amtliches Dashboard COVID19 öffentlich zugängliche Informationen zuletzt aktualisiert 26.05.2020 20:00:00 https://info.gesundheitsministerium.at/ dashboard_GenTod.html?l=de (2020).

30. Ministry of Health Saudi Arabia. $M O H$ News $-M O H:+45,000$ Recoveries and No Critical Cases or Deaths among Children https://www.moh.gov.sa/en/ Ministry/MediaCenter/News/Pages/News-2020-05-25-001.aspx (2020).

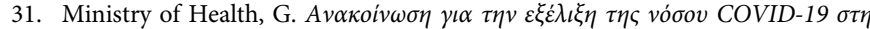

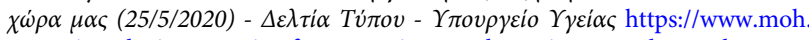
gov.gr/articles/ministry/grafeio-typoy/press-releases/7214-anakoinwsh-giathn-ekseliksh-ths-nosoy-covid-19-sth-xwra-mas-25-5-2020 (2020). 
32. Republic of Estonia Health Board. COVID-19 andmed seisuga 11.05.2020. https://www.terviseamet.ee/sites/default/files/Nakkushaigused/COVID-19/ ulevaade_11.05.2020.pdf (2020).

33. Republic of the Philippines Department of Health. COVID-19 Tracker https:// www.doh.gov.ph/covid19tracker (2020).

34. Ministry of Health New Zealand. COVID-19 - Current Cases https://www. health.govt.nz/our-work/diseases-and-conditions/covid-19-novelcoronavirus/covid-19-current-situation/covid-19-current-cases\#gender (2020).

35. Nacionalni inštitut za javno zdravje. Dnevno Spremljanje Okužb s SARS-CoV-2 (COVID-19) Sloveniji https://www.nijz.si/sl/dnevno-spremljanje-okuzb-s-sarscov-2-covid-19 (2020).

36. Public Health England. Weekly Surveillance Report in England Coronavirus (COVID-19). https://www.gov.uk/government/news/weekly-covid-19surveillance-report-published (2020).

37. Public Health Scotland. COVID-19 Statistical Report https://beta.isdscotland. org/find-publications-and-data/population-health/covid-19/covid-19statistical-report/ (2020).

38. OCHA Pakistan. Pakistan COVID - 19 Dashboard as of 22nd of May 2020. https://reliefweb.int/report/pakistan/pakistan-covid-19-dashboard-22nd-may2020 (2020).

39. Instituto Nacional de Salud. Coronavirus Colombia https://www.ins.gov.co/ Noticias/Paginas/Coronavirus.aspx (2020).

40. Ministereo de Salud Publica Ecuador. Coronavirus Ecuador - verified information on the arrival of COVID-19 in the country https:// coronavirusecuador.com/data/ (2020).

41. Gobierno de Mexico. COVID-19 Tablero México https://coronavirus.gob.mx/ datos/\#DOView (2020)

42. Ministry of Public Health Thailand. The Coronavirus Disease 2019 Situation. https://ddc.moph.go.th/viralpneumonia/eng/index.php (2020).

43. Ministry of Health The Luxembourg Government. Coronavirus: COVID-19 https://msan.gouvernement.lu/en/dossiers/2020/corona-virus.html (2020).

44. Gugus Tugas Percepatan Penanganan COVID-19 Indonesia. Peta Sebaran https://covid19.go.id/peta-sebaran (2020).

45. Ministerio de Salud Publica Republica Dominicana. República Dominicana Dirección General de Epidemiología Boletín especial \#69 FECHA: 26/05/2020 HORA: 6:00pm https://www.msp.gob.do/web/?page_id=6948 (2020).

46. Ministerio de Salud Argentina. Sala de Situación Coronavirus online https:// www.argentina.gob.ar/salud/coronavirus-COVID-19/sala-situacion (2020).

47. Northern Ireland Department of Health An Roinn Slainte Mannystrie O Poustie. COVID-19 Testing Details https://app.powerbi.com/view? $\mathrm{r}=$ eyJrIjoiZGYxNjYzNmUtOTlmZS00ODAxLWE1YTEtMjA0NjZhMzlmN2JmIiwidCI6IjljOWEzMGRILWQ4ZDctNGFhNC05NjAwLTRiZTc2MjVmZjZjNSIsImMiOjh9 (2020).

48. Ministry of Health Republic of Ghana. COVID-19 Updates Ghana https:// www.ghanahealthservice.org/covid19/ (2020).

49. Ministry of Health Somalia. COVID-19 Dashboard Somalia http://moh.gov.so/ en/covid19/ (2020).

50. Ministry of Health \& Sanitation. Sierra Leone COVID-19 Update https://mohs. gov.sl/2020/06/21/sierra-leone-covid-19-update/ (2020).

51. Haiti Ministere De La Sante Publique et de la Population. Direction D'epidemiologie Des Laboratoire Set De La Recherche https://chis.sisnu. net:8444/covid19/ (2020)

52. Ministry of Health \& Wellness Jamaica. COVID-19 Update: 21 More Jamaicans Recovered https://www.moh.gov.jm/covid-19-update-21-morejamaicans-recovered/ (2020).

53. Nigeria Centre for Disease Control. COVID-19 Situation Report Situation Report 92 Saturday, 30th May 2020 https://ncdc.gov.ng/diseases/sitreps/? $\mathrm{cat}=14$ \&name $=$ An update of COVID-19 outbreak in Nigeria (2020).

54. Bangladesh IEDCR. Bangladesh Covid-19 Update https://www.iedcr.gov.bd/ index.php/component/content/article/73-ncov-2019 (2020).

55. New York State Department of Health. Workbook: NYS-COVID19-Tracker https://covid19tracker.health.ny.gov/views/NYS-COVID19-Tracker/ NYSDOHCOVID-19Tracker-Map?\%3Aembed=yes\&\%3Atoolbar $=$ no\& $\%$ 3 Atabs $=\mathrm{n}(2020)$

56. Texas Health and Human Services. COVID-19 In Texas (Dashboard) https:// txdshs.maps.arcgis.com/apps/opsdashboard/index.html\#/ ed483ecd702b4298ab01e8b9cafc8b83 (2020).

57. Illinois Department of Public Health. COVID-19 Statistics http://www.dph. illinois.gov/covid19/covid19-statistics (2020).

58. Department of Health Pennsylvania. COVID-19 Data for Pennsylvania https:// www.health.pa.gov/topics/disease/coronavirus/Pages/May-Archive.aspx (2020).

59. Massachusetts Department of Public Health. COVID-19 Dashboard of Public Health Indicators. https://www.mass.gov/doc/covid-19-dashboard-may-212020/download (2020).
60. New Jersey Department of Health. COVID-19 Confirmed Case Summary. https://www.nj.gov/health/cd/documents/topics/NCOV/ COVID_Confirmed_Case_Summary.pdf (2020).

61. Michigan DHHS. Coronavirus - Michigan Data https:/www.michigan.gov/ coronavirus/0,9753,7-406-98163_98173-,00.html (2020).

62. California Department of Public Health. COVID-19 Public Dashboard https:// public.tableau.com/views/COVID-19PublicDashboard/Covid-19Public? embed $=y \&:$ display_count $=$ no\&:showVizHome $=$ no $(2020)$.

63. Washington State Department of Health. COVID-19 Data Dashboard https:// www.doh.wa.gov/Emergencies/NovelCoronavirusOutbreak2020COVID19/ DataDashboard (2020).

64. Department of Health State of Louisiana. Louisiana Coronavirus COVID-19 http://ldh.la.gov/Coronavirus/ (2020).

65. Maryland Department of Health. Coronavirus Data Dashboard https:// coronavirus.maryland.gov/ (2020).

66. Virginia Department of Health. Coronavirus Cases in Virginia https://www. vdh.virginia.gov/coronavirus/ (2020).

67. North Carolina DHHS. COVID-19: Cases https://covid19.ncdhhs.gov/ dashboard/cases (2020)

68. South Carolina DHEC. SC Demographic Data (COVID-19) https://www. scdhec.gov/infectious-diseases/viruses/coronavirus-disease-2019-covid-19/scdemographic-data-covid-19 (2020).

69. Alabama Public Health. Alabama COVID19 Information Hub https://covid19. alabama.gov/\#live-updates (2020).

70. Mississippi State Department of Health. Coronavirus COVID-19 https://msdh ms.gov/msdhsite/_static/14,0,420.html\#Mississippi (2020).

71. Ohio State Department of Health. COVID-19 Key Metrics Dashboard. https:// coronavirus.ohio.gov/wps/portal/gov/covid-19/dashboards/key-metrics/cases (2020).

72. Arkansas Department of Health. COVID-19 Case Update https://experience. arcgis.com/experience/c2ef4a4fcbe5458fbf2e48a21e4fece9 (2020).

73. The Indiana Data Hub. COVID-19 Case Demographics https://hub.mph.in. gov/dataset/covid-19-case-demographics/resource/2538d7f1-391b-4733-90b39e95cd5f3ea6 (2020).

74. Wisconsin Department of Health Services. COVID-19: Wisconsin Cases https://www.dhs.wisconsin.gov/covid-19/cases.htm (2020).

75. Minnesota Dept of Health. Minnesota Department of Health WEEKLY COVID-19 REPORT 5/28/2020. https://www.health.state.mn.us/diseases/ coronavirus/situation.html (2020).

76. Florida State Health Department. Coronavirus: cases and laboratory testing over time. https://floridahealthcovid19.gov/ (2020).

77. Kentucky Department of Public Health. KDPH COVID-19 Dashboard https:// kygeonet.maps.arcgis.com/apps/opsdashboard/index.html\#/ 543ac64bc40445918cf8bc34dc40e334 (2020).

78. Iowa Department of Public Health. Iowa COVID-19 Information-Case Counts https://coronavirus.iowa.gov/pages/case-counts (2020).

79. Missouri Department of Health and Senior Services. Missouri COVID-19 Dashboard http://mophep.maps.arcgis.com/apps/MapSeries/index.html? appid $=8 \mathrm{e} 01 \mathrm{a} 5 \mathrm{~d} 8 \mathrm{~d} 8 \mathrm{bd} 4 \mathrm{~b} 4 \mathrm{f} 85 \mathrm{add} 006 \mathrm{f} 9 \mathrm{e} 14 \mathrm{a} 9 \mathrm{~d}$ (2020).

80. Connecticut Department of Public Health. COVID-19 Update May 28, 2020 https://www.cdc.gov/coronavirus/2019-ncov/covid-data/covid-net/purpose(2020).

81. Rhode Island Department of Health. COVID-19 Response Data Hub https://ridepartment-of-health-covid-19-data-rihealth.hub.arcgis.com/ (2020).

82. NH Division of Public Health Services. Coronavirus Disease 2019 (COVID-19) in New Hampshire Weekly Summary Report - May 18, 2020. https://www. census.gov/data/tables/time-series/demo/popest/2010s-state-detail.html. (2020).

83. Vermont Department of Health. VT COVID-19 Dashboard - Public Beta v.1.0 https://vcgi.maps.arcgis.com/apps/opsdashboard/index.html\#/ 6128a0bc9ae14e98a686b635001ef7a7 (2020).

84. Maine DHHS. Novel Coronavirus 2019 (COVID-19) Airborne Disease Surveillance Epidemiology Program https://www.maine.gov/dhhs/mecdc/ infectious-disease/epi/airborne/coronavirus.shtml\#situation (2020).

85. Oklahoma State Department of Health. COVID-19 Current Situation https:// coronavirus.health.ok.gov/ (2020)

86. Alaska Department of Health and Social Services. Alaska Coronavirus Response https://coronavirus-response-alaska-dhss.hub.arcgis.com/ (2020).

87. Arizona Department of Health Services. ADHS - Data Dashboard https:// www.azdhs.gov/preparedness/epidemiology-disease-control/infectiousdisease-epidemiology/covid-19/dashboards/index.php (2020).

88. Colorado Department of Public Health and Environment. Colorado Official State Web Portal https://covid19.colorado.gov/covid-19-data (2020).

89. Delaware Environmental Public Health Tracking Network. State of Delaware - My Healthy Community https://myhealthycommunity.dhss.delaware.gov/ locations/state (2020). 
90. West Virginia Department of Health \& Human Resources. Coronavirus Disease 2019 (COVID-19) https://dhhr.wv.gov/COVID-19/Pages/default.aspx (2020).

91. Oregon Public Health Division. COVID-19 Weekly Report Published May 19, 2020. https://www.oregon.gov/oha/PH/DISEASESCONDITIONS/ DISEASESAZ/Emerging Respitory Infectio (2020).

92. North Dakota Health. North Dakota Coronavirus Cases https://www.health. nd.gov/diseases-conditions/coronavirus/north-dakota-coronavirus-cases (2020).

93. New Mexico Department of Health. COVID-19 Public Dashboard https:// cvprovider.nmhealth.org/public-dashboard.html (2020).

94. Nevada Department of Health and Human Services. Coronavirus (COVID-19) in Nevada https://nvhealthresponse.nv.gov/ (2020).

95. Montana Communicable Disease Epidemiology. Interim Analysis of COVID19 cases in Montana (as of 5/15/2020). https://dphhs.mt.gov/publichealth/ cdepi/diseases/coronavirusmt/demographics (2020).

96. Kansas Department of Health \& Environment. COVID-19 Cases in Kansas https://www.coronavirus.kdheks.gov/160/COVID-19-in-Kansas (2020).

97. Idaho Division of Public Health. DPH Idaho COVID-19 Dashboard.V2 https:// public.tableau.com/profile/idaho.division.of.public.health\#!/vizhome/ DPHIdahoCOVID-19Dashboard V2/Storyl (2020).

98. Wyoming Department of Health. COVID-19 Map and Statistics https://health. wyo.gov/publichealth/infectious-disease-epidemiology-unit/disease/novelcoronavirus/covid-19-map-and-statistics/ (2020).

99. Sawyer, C. C. Child mortality estimation: estimating sex differences in childhood mortality since the 1970s. PLoS Med. 9, e1001287 (2012).

100. Flanagan, K. L., Fink, A. L., Plebanski, M. \& Klein, S. L. Sex and Gender Differences in the Outcomes of Vaccination over the Life Course. Annu Rev. Cell Dev. Biol. 33, 577-599 (2017).

101. Klein, S. L. \& Flanagan, K. L. Sex differences in immune responses. Nat. Rev. Immunol. 16, 626-638 (2016).

102. Schroder, J., Kahlke, V., Staubach, K. H., Zabel, P. \& Stuber, F. Gender differences in human sepsis. Arch. Surg. 133, 1200-1205 (1998).

103. Karlberg, J., Chong, D. S. Y. \& Lai, W. Y. Y. Do Men Have a Higher Case Fatality Rate of Severe Acute Respiratory Syndrome than Women Do? Am. J. Epidemiol. https://doi.org/10.1093/aje/kwh056 (2004).

104. Leong, H. N. et al. SARS in Singapore-predictors of disease severity. Ann. Acad. Med. Singap. 35, 326-331 (2006).

105. Alghamdi, I. G. et al. The pattern of Middle East respiratory syndrome coronavirus in Saudi Arabia: a descriptive epidemiological analysis of data from the Saudi Ministry of Health. Int J. Gen. Med. 7, 417-423 (2014).

106. Abdullah, M. et al. Gender effect on in vitro lymphocyte subset levels of healthy individuals. Cell. Immunol. 272, 214-219 (2012).

107. Lee, B. W. et al. Age- and sex-related changes in lymphocyte subpopulations of healthy Asian subjects: from birth to adulthood. Cytometry 26, 8-15 (1996).

108. Lisse, I. M. et al. T-lymphocyte subsets in West African children: impact of age, sex, and season. J. Pediatr. 130, 77-85 (1997).

109. Delmas, M. C. et al. Gender difference in CD4+cell counts persist after HIV-1 infection. SEROCO Study Group. AIDS 11, 1071-1073 (1997).

110. Mori, M. et al. Sex Differences in Antiretroviral Therapy Initiation in Pediatric HIV Infection. PLoS One 10, e0131591 (2015).

111. Ruel, T. D. et al. Sex differences in HIV RNA level and CD4 cell percentage during childhood. Clin. Infect. Dis. 53, 592-599 (2011).

112. Hewagama, A., Patel, D., Yarlagadda, S., Strickland, F. M. \& Richardson, B. C. Stronger inflammatory/cytotoxic T-cell response in women identified by microarray analysis. Genes Immunity 10, 509-516 (2009).

113. Stoica, G., Macarie, E., Michiu, V. \& Stoica, R. C. Biologic variation of human immunoglobulin concentration. I. Sex-age specific effects on serum levels of IgG, IgA, IgM and IgD. Med. Interne. 18, 323-332 (1980).

114. Klein, S. L., Marriott, I. \& Fish, E. N. Sex-based differences in immune function and responses to vaccination. Trans. R. Soc. Trop. Med. Hyg. https:// doi.org/10.1093/trstmh/tru167 (2014).

115. Engler, R. J. et al. Half- vs full-dose trivalent inactivated influenza vaccine (2004-2005): age, dose, and sex effects on immune responses. Arch. Intern. Med. 168, 2405-2414 (2008).

116. Furman, D. et al. Systems analysis of sex differences reveals an immunosuppressive role for testosterone in the response to influenza vaccination. Proc. Natl Acad. Sci. U.S.A. https://doi.org/10.1073/ pnas.1321060111 (2014).

117. Voigt, E. A. et al. Sex differences in older adults' immune responses to seasonal influenza vaccination. Front. Immunol. 10, 180 (2019).

118. Berghöfer, B. et al. TLR7 Ligands Induce Higher IFN- $\alpha$ Production in Females. J. Immunol. 177, 2088-2096 (2006)

119. Laffont, S. et al. X-Chromosome Complement and Estrogen Receptor Signaling Independently Contribute to the Enhanced TLR7-Mediated IFN- $a$ Production of Plasmacytoid Dendritic Cells from Women. J. Immunol. 193, 5444-5452 (2014).
120. Seillet, C. et al. The TLR-mediated response of plasmacytoid dendritic cells is positively regulated by estradiol in vivo through cell-intrinsic estrogen receptor a signaling. Blood 119, 454-464 (2012).

121. Webb, K. et al. Sex and pubertal differences in the type 1 interferon pathway associate with both $\mathrm{X}$ chromosome number and serum sex hormone concentration. Front. Immunol. 10, 3167 (2019).

122. Ziegler, S. M. \& Altfeld, M. Human Immunodeficiency Virus 1 and Type I Interferons-Where Sex Makes a Difference. Front. Immunol. 8, 1224 (2017).

123. Ziegler, S. M. et al. Human pDCs display sex-specific differences in type I interferon subtypes and interferon alpha/beta receptor expression. Eur. J. Immunol. 47, 251-256 (2017).

124. Meier, A. et al. Sex differences in the Toll-like receptor-mediated response of plasmacytoid dendritic cells to HIV-1. Nat. Med 15, 955-959 (2009).

125. Trouillet-Assant, S. et al. Type I IFN immunoprofiling in COVID-19 patients. Clin. Chem. https://doi.org/10.1093/clinchem/hvaa089 (2020).

126. Spolarics, Z., Pena, G., Qin, Y., Donnelly, R. J. \& Livingston, D. H. Inherent X Linked Genetic Variability and Cellular Mosaicism Unique to Females Contribute to Sex-Related Differences in the Innate Immune Response. Front Immunol. 8, 1455 (2017).

127. Bianchi, I., Lleo, A., Gershwin, M. E. \& Invernizzi, P. The X chromosome and immune associated genes. J. Autoimmun. 38, J187-J192 (2012).

128. Qu, K. et al. Individuality and variation of personal regulomes in primary human T cells. Cell Syst. 1, 51-61 (2015).

129. Wang, J. et al. Unusual maintenance of X chromosome inactivation predisposes female lymphocytes for increased expression from the inactive X. Proc. Natl Acad. Sci. https://doi.org/10.1073/pnas.1520113113 (2016).

130. Khan, D. \& Ansar Ahmed, S. The Immune System Is a Natural Target for Estrogen Action: Opposing Effects of Estrogen in Two Prototypical Autoimmune Diseases. Front Immunol 6, 635 (2015).

131. Polanczyk, M. J. et al. Cutting edge: estrogen drives expansion of the CD4+ CD25+regulatory T cell compartment. J. Immunol. 173, 2227-2230 (2004).

132. Tyagi, A. M. et al. Estrogen deficiency induces the differentiation of IL-17 secreting Th17 cells: a new candidate in the pathogenesis of osteoporosis. PLoS One 7, e44552 (2012).

133. Pauklin, S., Sernandez, I. V., Bachmann, G., Ramiro, A. R. \& Petersen-Mahrt, S. K. Estrogen directly activates AID transcription and function. J. Exp. Med. 206, 99-111 (2009).

134. Jilma, B. et al. Effects of 17 beta-estradiol on circulating adhesion molecules. J. Clin. Endocrinol. Metab. 79, 1619-1624 (2018).

135. Bouman, A., Heineman, M. J. \& Faas, M. M. Sex hormones and the immune response in humans. Hum. Reprod. Updat. 11, 411-423 (2005).

136. Ding, T. et al. A Multi-hospital Study in Wuhan, China: Protective Effects of Non-menopause and Female Hormones on SARS-CoV-2 infection. medrxiv https://doi.org/10.1101/2020.03.26.20043943 (2020).

137. Jose, R. J. \& Manuel, A. COVID-19 cytokine storm: the interplay between inflammation and coagulation. Lancet Respiratory Med. 8, e46-e47 (2020).

138. Page, S. T. et al. Effect of medical castration on CD4+CD25+T cells, CD8+T cell IFN- $\gamma$ expression, and NK cells: a physiological role for testosterone and/ or its metabolites. Am. J. Physiol. Endocrinol. Metab. 290, E856-E863 (2006).

139. Chakravarty, D. et al. Sex differences in SARS-CoV-2 infection rates and the potential link to prostate cancer. Commun. Biol. 3, 1-12 (2020).

140. Fulop, T. et al. Immunosenescence and Inflamm-Aging As Two Sides of the Same Coin: Friends or Foes? Front Immunol. 8, 1960 (2017).

141. Márquez, E. J. et al. Sexual-dimorphism in human immune system aging. Nat. Commun. 11, 751 (2020).

142. Gubbels Bupp, M. R., Potluri, T., Fink, A. L. \& Klein, S. L. The Confluence of Sex Hormones and Aging on Immunity. Front. Immunol. 9, 1269 (2018).

143. Wan, Y., Shang, J., Graham, R., Baric, R. S. \& Li, F. Receptor Recognition by the Novel Coronavirus from Wuhan: an Analysis Based on Decade-Long Structural Studies of SARS Coronavirus. J. Virol. 94, e00127-20 (2020).

144. Cai, G. Bulk and single-cell transcriptomics identify tobacco-use disparity in lung gene expression of ACE2, the receptor of 2019-nCov. medRxiv https:// doi.org/10.1101/2020.02.05.20020107 (2020)

145. Zhao, Y. et al. Single-cell RNA expression profiling of ACE2, the putative receptor of Wuhan 2019-nCov. bioRxiv 2020.01.26.919985. biorxiv https://doi. org/10.1101/2020.01.26.919985 (2020).

146. Bukowska, A. et al. Protective regulation of the ACE2/ACE gene expression by estrogen in human atrial tissue from elderly men. Exp. Biol. Med. 242, 1412-1423 (2017).

147. Culebras, E. \& Hernández, F. ACE2 is on the X chromosome: could this explain COVID-19 gender differences? Eur. heart J. 41(32), 3095-3095 (2020).

148. Benjamin, E. J. et al. Heart Disease and Stroke Statistics-2017 Update: A Report From the American Heart Association. Circulation 135, e146-e603 (2017).

149. Saeedi, P. et al. Global and regional diabetes prevalence estimates for 2019 and projections for 2030 and 2045: Results from the International Diabetes Federation Diabetes Atlas, 9th edn. Diabetes Res Clin. Pr. 157, 107843 (2019). 
150. Guan, W. et al. Comorbidity and its impact on 1590 patients with Covid-19 in China: A Nationwide Analysis. Eur. Respir. J. 2000547 (2020). Eur. Respir. J. https://doi.org/10.1183/13993003.00547-2020 (2020).

151. World Health Organization. Global Adult Tobacco Survey Fact Sheet. https:// www.who.int/docs/default-source/wpro-documents/countries/china/2018gats-china-factsheet-cn-en.pdf?sfvrsn=3f4e2da9_2 (2018).

152. Judah, G. et al. Experimental pretesting of hand-washing interventions in a natural setting. Am. J. Public Health 99(Suppl 2), S405-S411 (2009).

153. World Health Organization. Addressing Sex And Gender In Epidemic-prone Infectious Diseases. (World Health Organization, 2007).

154. Regitz-Zagrosek, V. Sex and gender differences in health. Science \& Society Series on Sex and Science. EMBO Rep. 13, 596-603 (2012).

155. Morgan, R. \& Klein, S. L. The intersection of sex and gender in the treatment of influenza. Curr. Opin. Virol. 35, 35-41 (2019).

156. Bischof, E., Oertelt-Prigione, S., Morgan, R. \& Klein, S. Towards Precision Medicine: Inclusion of Sex and Gender Aspects in COVID-19 Clinical Studies -Acting Now before It Is Too Late-A Joint Call for Action. Int. J. Environ. Res. Public Health 17, 3715 (2020).

157. Worldometers.info. Worldometer. Dover, Delaware, U.S.A. (Worldometers. info, 2020).

158. Balduzzi, S., Rücker, G. \& Schwarzer, G. How to perform a meta-analysis with R: a practical tutorial. Evid. Based Ment. Health 22, 153-160 (2019).

\section{Acknowledgements}

KW is funded by the Crick African Network, African Career Accelerator Award (CANB0001/01). This work is funded by a Centre of Excellence (Centre for Adolescent Rheumatology Versus Arthritis) grant to LRW (21593) as well as grants from Medical Research Council (MR/R013926/1) and Great Ormond Street Children's Charity to LRW and NIHR Biomedical Research Centre at University College London Hospital to CC (BRC/ III 525). ECR and NMdG are supported by a Medical Research Foundation Lupus Fellowship to ECR (MRF-057-0001-RG-ROSS-C0797). LRW and CD are supported by the NIHR Biomedical Research Centre at Great Ormond Street Hospital. HP is supported by a Versus Arthritis Studentship to CC (22203). The views expressed are those of the author(s) and not necessarily those of the NHS, the NIHR or the Department of Health. KW, ECR and CTD would like to thank this exceptional team for their dedication to getting these vital data gathered quickly and efficiently, with many working remotely, caring for young families and working on the frontline, and some working while unwell in quarantine. The funders of this study had no role in study design, data collection, data analysis, data interpretation, or writing of the report. The corresponding authors had full access to all the data in the study and had final responsibility for the decision to submit for publication.

\section{Author contributions}

K.W., E.C.R., C.T.D., H.P., N.M.d.G., A.R., C.R. wrote the manuscript. C.T.D. analysed data, performed meta-analysis and generated figures. H.P., N.M.d.G., A.R., C.R., C.T.D. searched for, evaluated and gathered data. C.C. and L.R.W. edited and contributed to the manuscript. E.C.R., C.T.D., K.W., L.R.W. and C.C. obtained grant funding that supported this work.

\section{Competing interests}

The authors declare no competing interests.

\section{Additional information}

Supplementary information is available for this paper at https://doi.org/10.1038/s41467020-19741-6.

Correspondence and requests for materials should be addressed to K.W. or C.T.D.

Peer review information Nature Communications thanks Katie Flanagan, Hannelore Lotter and the other, anonymous, reviewer(s) for their contribution to the peer review of this work. Peer reviewer reports are available.

Reprints and permission information is available at http://www.nature.com/reprints

Publisher's note Springer Nature remains neutral with regard to jurisdictional claims in published maps and institutional affiliations.

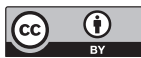

Open Access This article is licensed under a Creative Commons Attribution 4.0 International License, which permits use, sharing, adaptation, distribution and reproduction in any medium or format, as long as you give appropriate credit to the original author(s) and the source, provide a link to the Creative Commons license, and indicate if changes were made. The images or other third party material in this article are included in the article's Creative Commons license, unless indicated otherwise in a credit line to the material. If material is not included in the article's Creative Commons license and your intended use is not permitted by statutory regulation or exceeds the permitted use, you will need to obtain permission directly from the copyright holder. To view a copy of this license, visit http://creativecommons.org/ licenses/by/4.0/.

(C) The Author(s) 2020 